\author{
Reinhardt Fourie An analysis of the bodily spatial \\ and Melissa Adendorff power relations in Agaat \\ Reinhardt Fourie is a lecturer in the \\ Department of English Studies at the \\ University of South Africa. \\ Email: fourir@unisa.ac.za. \\ Melissa Adendorff is a lecturer in the \\ Unit for Academic Literacy at the \\ University of Pretoria. \\ Email: melissa.adendorff@up.ac.za.
}

\title{
An analysis of the bodily spatial power relations in Agaat by Marlene van Niekerk
}

The aim of this article is to explore the power relations portrayed through the bodily spatial interaction of the characters of Milla and Agaat in Marlene van Niekerk's 2004 novel, Agaat. This interaction is analysed according to the theory of Thirding-asOthering posited by Henri Lefebvre and Edward Soja in terms of the body in space. The body in space is interpreted through agency which is exemplified in the intimacy of the relations of these two bodies through the actions of bathing, giving birth, and the physical aspects of the process of "civilising" the child character of Agaat. Through an analysis of three sets of incidents and scenes which illustrate the physical inhabitation of space through agency, the power relations between Milla and Agaat are exemplified and discussed. The analysis culminates in the conclusion that the relationship between Milla and Agaat is a cyclical power play that does not come to any pure form of dominance or submission because of the inhabitation that they enact through each other. With agency being tantamount to inhabitation and assertion of power, Agaat has the ultimate power on the farm through Milla, as Milla's body is othered by her illness and finally her death. Keywords: Agaat, Marlene van Niekerk, Thirding-as-0thering, spatial inhabitation, power, body in space.

\section{Introduction}

The aim of this article is to explore the power relations portrayed through the bodily spatial interaction of the characters of Milla and Agaat in Marlene van Niekerk's 2004 novel, Agaat. This interaction is analysed according to the theory of Thirding-asOthering posited by Henri Lefebvre and Edward Soja in terms of the body in space. The body in space is interpreted through agency which is exemplified in the intimacy ${ }^{1}$ of the relations of these two bodies through the actions of bathing, giving birth, and the physical aspects of the process of "civilising" the child character of Agaat.

Following the literary and historical contextualisation of the novel, a theoretical overview is provided that sketches existing research on Agaat, the concepts of Critical Spatiality, Thirding-as-Othering, and the body in space. The latter three concepts are then applied in the analysis of the incidents of bathing, taming, ${ }^{2}$ and birthing. 


\section{Literary and historical contextualisation}

Since the publication of Agaat in 2004, the novel has been praised both nationally and internationally. The novel has been awarded the prestigious South African Hertzog Prize, inter alia, and its English translation by Michiel Heyns, published in some territories as The Way of the Women (2006), has spread the novel to an international audience that has been very positive in its reception.

Subsequently, scholarly interest in the novel has increased exponentially during the past decade. An overview of published research reveals that the novel is often approached from a postcolonial perspective. A number of studies have been conducted on the challenges of translating Agaat from Afrikaans into English, while there has even been an analysis of the novel within the legal context of landownership. Due to the limited scope of this study, reference will only be made to other studies on the novel that are related to the focus of this article: the portrayal of power relations through the bodily spatial interaction of the characters of Milla and Agaat.

The component of the research conducted on Agaat that falls within postcolonial studies has a strong focus on the novel as plaasroman (farm novel) and the fraught relationship between the colonised Agaat and coloniser Milla. Central to this has been the investigation of Agaat as the Other/other, as is the case in an article by Loraine Prinsloo and Andries Visagie (43-62).

According to Prinsloo and Visagie, Agaat represents the colonised other of the De Wet family. Prinsloo and Visagie (51-8) contend that Agaat's identity as other is informed by her relationship with the white landowner, Milla, concluding that while Agaat is not entirely part of "them" (being the subordinate group of coloured farm workers on Grootmoedersdrift), she does not become part of "us" (the dominant, white, landowning family) either (Prinsloo \& Visagie 58). ${ }^{3}$ With reference to Levinas's (149) conception of the other, Prinsloo and Visagie also note that Agaat forms part of a larger postcolonial discourse:

In her farm novel Agaat, the representation of the brown domestic worker, Agaat Lourier, is interspersed with the realisation that is so characteristic of the impeded white postcolonial author, namely that any attempt to represent the other is embedded in an age-old colonial discourse about the other that from the outset problematises and undermines the credibility of white authors. As opposed to the colonial period, the postcolonial author becomes aware of the countenance of the

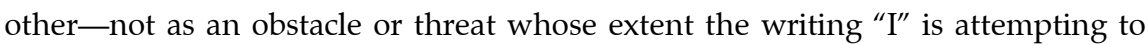
determine, but as something against which the " $\mathrm{I}$ " must be measured (our translation). ${ }^{4}$

Agaat can thus also be viewed as an examination of the limitations the postcolonial (Afrikaans) writer is faced with when writing about the other (Prinsloo \& Visagie 44).

In a similar vein, Ena Jansen (102-33) considers the representation of the maid in a selection of Afrikaans novels, including Agaat. She indicates that due to the nature of 
their working situation, maids always find themselves in strictly delimited power relations (Jansen 114). Although they are privy to some of the most intimate parts of a family's life (particularly in terms of the so-called madam), there is no doubt about their position as subordinate in the family. While Jansen (102-33) focuses mainly on the representation of maids in literature, the stringently defined power relations maids are bound to certainly have bearing on the formation of their identities, both for the maid and the madam. In this study, the specificities of the maid/madam relationship between Milla and Agaat will as such not be discussed. However, the power relations between these characters are central to the analysis.

Homi Bhabha's "mimicry" is an important concept which has been utilised in postcolonial analyses of Agaat. According to Bill Ashcroft, Graham Griffiths and Helen Tiffin (124) the term "mimicry" in postcolonial theory describes "the ambivalent relationship between colonizer and colonized" - therefore between self and other. Mimicry is an adoption of the coloniser's cultural habits, assumptions, institutions and values, and because it is an adoption, it is "never a simple reproduction of those traits"(Ashcroft, Griffiths \& Tiffin 125). Bhabha (126) defines the term as "the desire for a reformed, recognizable Other, as a subject of a difference that is almost the same, but not quite". While the coloniser wants the colonised to adopt his/her (the coloniser's) cultural habits, assumptions and values, he/she only wants this to a certain extent (Fourie 28). Bhabha (127) explains this on the basis of the ambivalence of mimicry ("almost the same, but not quite"), which "does not merely 'rupture' the discourse, but becomes transformed into an uncertainty which fixes the colonial subject as a 'partial' presence". Ashcroft, Griffiths and Tiffin (125) point out that mimicry thus reveals the limitations of the colonial discourse's authority, and as a result of this, the mimicry is also possibly mockery. This menacing feature-always only suggesting the presence of some other identity, hiding something that cannot be discerned, challenging the authority of colonial discourse-is explained by Bhabha (131):

As Lacan reminds us, mimicry is like camouflage, not a harmonization or repression of difference, but a form of resemblance that differs/defends presence by displaying it in part, metonymically. Its threat $[\ldots]$ comes from the prodigious and strategic production of conflictual, fantastic, discriminatory "identity effects" in the play of a power that is elusive because it hides no essence, no "itself".

Fourie (28) summarises how mimicry functions in Agaat:

The uneasiness of the colonial interpreter (Milla in Agaat) comes as a result of two problematic issues in the question of self/other. Firstly it is the ability to recognise familiar elements of its own "culture" ("the same") in the colonised (and the knowledge that there is something more). Secondly it is the inability to recognise anything but that ("the difference"). Furthermore, mimicry shows just how constructed the coloniser's identity is. As such, mimicry exposes just how performative colonial power is. 
For Willie Burger (178), explorations of self/other and "the central position of the mirror as a recurring metaphor in [Agaat] invites a Lacanian approach" to the novel. He focuses specifically on language as a means through which the self can attempt to understand the other. However, he notes that "it is impossible for one subject to know another as the other is always taken up in the subject's language" (Burger 178). Milla's attempt to understand Agaat is central to Van Niekerk's novel, as Milla at one point wonders (by that point echoing the thoughts of the reader): "What must it feel like to be Agaat? How could you ever find that out? Would you be able to figure out what she was saying if she could explain it? She would have to explicate it in a language other than the tongue you had taught her" [474]). ${ }^{5}$ While Burger (192) acknowledges the limitations imposed by language on the process of the self understanding the other, he also points to how the body and bodily interaction presents another way of knowing:

Through language the mirror surface can be a rendezvous point with the other. With Milla there is the hope that it would be possible. And she and Agaat make progress in that direction. The bond between them progresses-indeed, she dies with Agaat's hand in her hand. And with this much more is also said concerning the possibility of knowing the other-the body and all the familiarity with the most intimate bodily functions between people bring in another way an intimacy, one besides that of the level of language, a possibility to be able to know (our translation). ${ }^{6}$

Through the use of Elizabeth Grosz's notion of the embodiment of space (2001), Lara Buxbaum ("Embodying") explores Agaat within the context of Van Niekerk's greater oeuvre. She specifically focuses on how Van Niekerk's fiction "challenges conventional understandings of the relationship between corporeality and spatiality" (Buxbaum, "Embodying" 29). Buxbaum convincingly argues that Milla's story, her identity and sense of self are inexplicably linked to the land (35-9). Similarly, Agaat is also aware of how her identity is linked to place: "Agaat is [...] simultaneously aware of the geographical barriers governing her movement and of her body as a racialised place which dictates her identity, her place" (39).

In another article, Buxbaum ("Remembering") explores how the protagonists in Triomf and Agaat narrate their trauma through their wounded bodies. She indicates that there is a clear suggestion that trauma must be confronted, even though this is only possible through the medium of the body:

In both Triomf and Agaat, the revelation of a tortured past is mirrored by the exposure of the victims' fragmented bodies. It is only when characters are faced with the irrefutable evidence of trauma as wreaked on each other's bodies that they are forced to reckon with and recognise the truth of their familial and national narratives and perhaps initiate healing. (98) 
In her conclusion, Buxbaum (98) echoes Burger (192) when she says "If words fail, bodies can speak".

This article aims to further illuminate the intricacy of the relationship between Milla and Agaat through an analysis of the characters' bodily spatial interaction and what this may ultimately reveal about the power relations between them.

\section{Theoretical overview}

David Greene (375) states that "it is implicit in the Newtonian worldview that space logically precedes human consciousness of spatially located objects, that space is indifferent to the particular objects that occupy it". Space is incumbent in the most "primitive consciousness", and the concept of spatiality develops and becomes more refined through the development of a person's "reflexive awareness" as that person sees and perceives the world (Greene 378).

The study of space is, therefore, essentially, a humanistic undertaking, because it is only understood through the experience of "sensation, perception, and conception" (Tuan 388). "The space we can perceive spreads out before and around us, and is divisible into regions of differing quality" (Tuan 399). Yi-Fu Tuan (399) explains the visual interpretation of and cognition of space as follows: far away from the body, a person perceives a seemingly "static" space with indistinct objects in it. Closer to the body is the visual-aural zone, through which space is interpreted through both sight and sound. Next to the body is the affective zone, within which space is experienced through sight, sound, smell, and touch.

The fact that spatiality stems from awareness and perception is related to the fact that, according to Henri Lefebvre (405), "the whole of social space proceeds from the body". When the body is understood in spatial terms, the senses "prefigure the layers of social space and their interconnections" (Lefebvre 405). The body's perception of space, whether active or passive, is what creates a spatial understanding of the world for the individual who inhabits that body.

Critical Spatiality and related spatial theories, such as the theories of boundaries, analyse how a particular place (and its inherent space) is constructed through the perceptions of it, and attributions made to it in terms of the psychosocial perceptions and understandings of its inhabitants at a given time (Matthews 165-8). This can be extended to include an interpretation of the human body as a space, as the body is a physical location, and has psychosocial attributes due to its existence in a social reality; a relevant extension by virtue of the fact that Critical Spatiality encapsulates the physical location proper, individual cognitive associations as well as cultural meanings that are explored in terms of the social dynamics that occur within it subjectively and reflectively (Matthews 168). 
The creation of an "other" space on the margins of a society is directly related to how a society's power relations dictate how a space is inhabited. Foucault identified a "power-knowledge-space complex" which "designates an overlapping bundle of ways of acting, modes of thinking, seeing, speaking, and understanding, as well as modes of coercion and strategies of production" (West-Pavlov 147). The power-knowledge-space complex allows for those spatial inhabitants with power to banish other inhabitants to the margins of the society, brandishing them as outsiders, and essentially, "other".

Edward Soja's and Henri Lefebvre's theory of Critical Spatiality is based on premises which govern the experience of a space, and can be categorised as follows (Flanagan 15-43):

1. Spatial Practice: espace perçu (perceived space), which serves as the medium and outcome of human activity, behaviour and experience [Firstspace];

2. Representations of Space: espace conçu (conceived space), which serves as the mental spaces that represent power, ideology, control and surveillance, and whereby resistance to these relations make them visible [Secondspace];

3. Representational Spaces: espace vécu (lived space), which are spaces that are directly lived, spaces of freedom and change [Thirdspace].

Lefebvre's lived spaces are the spaces in which otherness becomes prominent, due to the fact that through a society inhabiting a space, having given it certain attributes, that society's power dynamics become apparent. This occurs because the attributions made by a society are intrinsically based in power and knowledge, resonant of Foucault's power-knowledge-space complex (Flanagan 15-43). Through social practices which occur in a given place, representations of space are made, which lead to the existence of representational spaces.

Thirdspace comprises the physical of Firstspace and the emotional of Secondspace simultaneously, and within Thirdspace, these conceptions become a "double illusion" that gives birth to a social space with two distinct features; one being that it is a field which can be separated from the physical and mental, and two, that it becomes an "approximation for an all-encompassing mode of spatial thinking" (Soja 62).

Soja (60) explores Thirdspace in a more in-depth manner, introducing Thirdingas-Othering in Lefebvre's terms of it being "a 'moment' that partakes of the original pairing but is not just a simple combination or an 'in between' position along some all-inclusive continuum". Thirding introduces the other into the dualistic pairing of what is and what isn't, and thus, the idea of the trialectics can be traced to the dualistic reflexive thought of opposites, such as the relationships between subject-object, continuity-discontinuity, open-closed, as seen in the paradigm of Western philosophy. This binary opposition has become ineffectual, though, as the signifier and the signified are inherently more than a relation between two terms. "One always has Three. There is always the Other" (Lefebvre 225, 143). Thirding-as-Othering becomes either a method 
of empowerment to the othered, or a means of torment and punishment. In Agaat, the assimilation of the bodily spaces of Milla and Agaat represents Thirding-as-Othering, as their cumulative spatial inhabitation becomes the other bodily space that is inherent in their individual bodies. The power dynamic of this Thirding-as-Othering oscillates between Milla enforcing the othering upon Agaat, and vice versa.

The process of othering has been described as the "discursive process by which powerful groups who may or may not make up a numerical majority, define subordinate groups into existence in a reductionist way which ascribes problematic and/ or inferior characteristics to these subordinate groups" (Jensen 65). This process ensures that the powerful groups retain their power and gain more power, through the subjugation of their subordinates. This process plays an important role in the formation of the identities of the subordinates, or others, as it gives them the choice to accept their banishment or to rebel against it. In terms of how this process influences the respective identities of Milla and Agaat, see Buxbaum ("Embodying", "Remembering"), Prinsloo \& Visagie (43-62) and Jansen (102-33).

This choice means that the human body becomes a centre of power in its own right, through the potentiality of taking the power to act, and becoming a space of othering when physical ramifications for other behaviour are exacted upon the body in the form of punishment. This ties in with Foucault's theory that the body is a space that exists for the exercise of discipline as well as punishment.

The potentiality of action and its inherent intent and its own power cannot occur outside of space and place. This is because the "lived body" is a cohesive entity that has a sense of place, past (memories), and power inherent to place. "The body is the only aspect of our being-individual or collective-capable of performing place, that is to say, making place a living reality" (Casey 718).

The world that a person meets through his/her body is a socially constructed world within which that body has to function. The world within which a body functions is ruled by bodily interaction, to an extent, and as such, "one's self-concept is constructed out of how one understands certain impressions that are given off in the course of face-to-face interaction" (Waskul \& Vannini 299). This means that the concept of the self is rooted within the bodily expression of communication, as "presenting oneself is a communicative act" (Waskul \& Vannini 300).

The human body is conceived of in terms of the culture and society in which the given body has to function. These societies have different conceptions of what the body should look like, and it should function, and within these parameters, body distortions take on significance.

The human body in society functions on three levels: the first is that of the individual's self-experience in relation to the group experience; the role the body plays in the production of social meanings); and the body's role in power relations within a society as either the subject or object (McGuire 285). 
The fact that the bodily expressions of a disabled, or an ill individual, or any "other" individual with a body which does not conform to societal norms of bodily expression is distinguished by society, is due to the fact that a person, comprised of both physiological, psychological and psychosocial experiences, exists within the context of a society. A person thus exists within a social reality (Pilch 109), and his/her body and psyche are to be interpreted within the context of that reality.

Mike Featherstone and Bryan Turner (3) provide a context for the interpretation and study of the body in a societal reality as follows, based on the philosophy of Maurice Merleau-Ponty: "The body is a sentient entity and it is the capacity of the body as flesh to be both sentient and sensible, to be a visible-seer, a tangible-toucher, and an audible-listener". The perception of the body is rooted in a cultural interpretation of it, and is also "transmitted" to the individual culturally, in order to guide behaviour (Benoist \& Cathebras 858), "hence, the body becomes imagery and message".

Even though the "social body constrains the way the physical body is perceived", because the physical experience of the body is socially mediated, it "sustains a particular view of society" itself (Benoist \& Cathebras 858). The body's "selfhood" is based on an individual's own experience, as well as the individual's collective experience. These sets of experiences provide the body with "a constellation of physical signs with the potential for signifying the relations of persons to their contexts" (Comaroff 6).

The body in space is a living memory of the bodies that have been in that space before it, and is culturally bound to that bodily history. The body's cultural past is sedimented in "neuromuscular patterning and kinaesthetic memories-the way in which specific experiences and concepts of time and space are built into our bodily modus operandi" (Farnell 353). "Places hold experiences together" (Farnell 354).

Marga Viljoen (3-11) states that space is relative to the place where the "I" can be positioned, and that the situation of the "I" provides a sense of space and place that has the power to orientate people within that given space. This exemplifies how space is a social product, and how the situation of a body within a certain space renders both the body and the space as significant. The body's situation in space allows for social interaction with and social perception of a space. The body's inhabitation of a lived space, which makes it an embodied space is the location which is bound to human and bodily experience (Low 9). The body in space functions because in embodied spaces, human consciousness and experience "take on a material and spatial form" (Low 9).

The movement of the body in space is an undeniable action; "the dynamically embodied signifying practice of a human agent" (Farnell 343). The body in space has an undeniable agency and the "complex structures of bodily action" that people engage in are "laden with social and cultural significance" (Farnell 343). The agency of the body thus has an inherent "embodied intentionality to act" (Farnell 343), because it is only through action and movement that a body can inhabit a space. 
The body of an other, which has a body schema different to the social norm of bodily expression, is not isolated from the social bodily norm. Marga Viljoen (50) states that "I experience the other's body as a mysterious continuation of my own, and that we are 'tied together' in a sort of anonymous existence". The other body does not exist in isolation from the norm, because the body in space is both a subject and an object of perception and experience, and is in an interdependent relationship with the bodies around it in order to be perceived and to perceive. "Flesh is the formative medium of the subject and object" (Viljoen 75).

The body as space is the place where an individual "experience[s] pain, pass[es] through various kinds of ritual death and rebirth, and redefine[s] the relationship between self and society" (Schildkrout 320). The space of the body is an embodied space, and as such, has an effect on the individual whose body is in question. "Alterations of the embodied self-identity have either a positive or negative impact on one's emotional experience" (Waskul \& Vannini 298) in terms of pride or embarrassment.

\section{Analysis}

The following series of incidents illustrate the spatial power relations between Milla and Agaat. The first series of scenes involves Agaat bathing the paralysed Milla, and is focalised by Milla in her "present" state. The second series of events depicts the physical taming of Agaat, and is narrated through Milla's recollections of Agaat's childhood, as written up in her journals. The narrative structure of the text suggests that the reader can access these journal entries because it is Agaat reading them to the debilitated Milla. Finally, the birthing scene, which is narrated in "real time", shows the inhabitation of space through the body of the other. As will become clear in the analysis, these three scenes have been selected due to their importance in depicting the progression of the shift in terms of bodily power between the two characters.

The scene in which Agaat wakes, feeds, and bathes Milla exemplifies Thirding-asOthering in terms of their interaction, where there are no boundaries to Milla's body which Agaat does not cross. Agaat is in control of the space of Milla's body, and through the manipulation of Milla's body, Agaat inhabits the space for Milla, through Milla. Milla's bodily identity is dependent upon Agaat's manipulation of it. The first instance of this manipulation is evident when Agaat readjusts Milla in her bed. "She cranks me up, she pummels my pillows, she hoists my neck out of my body, she props up my head, she arrays me" (68). ${ }^{7}$ This is an external manipulation, though, and is focused on the Firstspace geography of Milla's body as a space which has to be moved into position within the space that it inhabits, namely, her bed. The boundary between the external bodily space and internal bodily space becomes breached the moment when Agaat wipes out the inside of Milla's mouth with a lukewarm, wet sponge. 
Agaat further exerts control over Milla as a spatial entity when she manipulates Milla's agency in the process of urination, after feeding Milla her morning tea. Agaat initially instructs Milla to urinate; "Well go on pee, Ounooi, I haven't got all day" (69) ("Nou toe pie, Ounooi, ek het nie heeldag tyd nie" [83]), and then coaxes Milla into the act through swirling water in the wash basin and pouring water from a glass into the basin, repeatedly.

While Milla attempts to ignore her, Agaat's presence and agency cannot be ignored, or escaped, and this presence in the face of what is considered to be private bodily function is an example of Thirding-as-Othering, as Milla is othered not only in the space of her bedroom, but also in the space of her body. Milla has no choice in the matter of Agaat's presence, nor Agaat's instructions to her to void her bladder. Milla's only option of dissociation from the moment is to think about the maps of her farm (which Agaat refuses to show her, othering her will in her space and enforcing the power dynamic between them), but in terms of dissociative agency, she is powerless over Agaat's influence in her space.

When Milla finally does urinate, Agaat addresses her as one would a child, saying "good girl" (70 "soet kind" [85]), once again reinforcing her dominance. Milla feels uncomfortable with Agaat's control of her bodily functions, and rebels against the Thirding-as-Othering to an extent, by not urinating and defecating in the nappy during the night, as she wishes to avoid Agaat's commentary (84). This rebellion, however, is not entirely successful in terms of the assertion of agency, as, when Agaat says, "You don't perhaps want the number two pan as well, seeing that you're in the swing of things now? [...] You don't want dung and piss over everything if you can help it" (70). ${ }^{8}$ Milla eventually defecates after being verbally shamed when Agaat says, “Otherwise we'll have no choice but to dose you with a Pink Lady again [...] a Pink Lady for the lady of Gdrift, it's five days now that her guts have been stuck. Perhaps that's what's making her so restless. What goes in must come out, after all, good heavens!" (70). ${ }^{9}$ In the original text, the exclamation "good heavens" is rendered as "allawerreld". This reinforces the tone which one would employ when addressing a child, once again reasserting the power dynamic. Unfortunately, this tone is lost in the translation. The fact that Agaat speaks to Milla, about Milla, in the third person also affirms this.

Agaat investigates Milla's urine, which is another invasion of the body as space. Following her commentary on this investigation, Milla's powerlessness is made apparent through the following:

What can I reply to that? What acrobatics of eyelids to convey: Your sarcasm is wasted on me. If I could die to deliver you, I would do so, today. Go and find somebody else to pee perfection for you on command. You're the one who wants to be perfect. You want me to be perfect. We must not be lacking in any respect. If you can do without, I must be able to do without, that's what you think. A perfect nurse. A perfect patient. As I taught you. $(72)^{10}$ 
This statement exemplifies Milla's despair at her othered nature, and her reliance on Agaat to do for her what she cannot do for herself. Through mentioning that she taught Agaat to be this way, Milla acknowledges a previous power dynamic in which she was the dominant figure, Thirding Agaat through instruction and spatial boundaries. This admission is rare throughout the novel, and it significant in this instance because Milla created the other who would end up othering her.

The aforementioned scene, which culminates in a "quarter-body wash" (71) ("kwartlyf se was" [85]), is reminiscent of the scene in which Milla bathed Agaat when she was a child. This scene signifies the start of the creation of the other. This incident is recorded in Milla's journal.

After finding and removing the toddler Agaat from her childhood home, Milla drugs her with Valerian root (485). This enables Milla to manipulate Agaat's body, inhabiting space with and through her, and establishing convenient physical dominance. Milla shaves Agaat's head, and while this was done to clean the child, it is a significant gesture inasmuch as it alters the appearance of the child to the extent that the identity of the body is altered, thus othered. Milla's suggestion that Agaat's decaying teeth be extracted is an invasion of the bodily boundary of the mouth, and once again exacts Milla's dominance over Agaat's body as space. During this scene, Milla refers to Agaat as "Asgat" (485), and states that she needs to find a new name for the child. The process of renaming, exemplifies the othering of the child's personality and sense of self, as once she is renamed, she is cleansed and "reborn" in the image that Milla projects for her: "And if your name is good, says [the priest] it's a selffulfilling prophecy. Like a holy brand it will be, like an immanent destiny, the name on the brow, to do good, to want to be good, goodness itself" $(416){ }^{11}$

Agaat's attempts at inducing Milla's urination stem from her instruction in potty training where Milla also poured water from a glass into a beaker, and when Agaat is unsuccessful at urinating and defecating in the potty as instructed, Milla puts her in a nappy. This is re-enacted with the othered Milla. Agaat's rebellion against Milla's ablutionary authority is exemplified when Saar points out that though Agaat urinates in her potty voluntarily, she defecates in the garden, when she assumes that she is not under surveillance (501).

When Milla chastises Agaat for this, she threatens the child with the withholding of treats (jelly): "Jelliedreigement werk goed" (502) ("Jelly threat works well" [414]). Agaat then complies with Milla's ablutionary instruction in order to get her treat. This incident is not met with the pride and accompanying treat, however, as Milla chastises Agaat for showing her what she had done in the potty, and says that she will only get the jelly now, if she were to speak in full sentences. This initiates the co-dependent feature of not being able to be perfect in the eyes of the object, while having the subject strive to please in every way. As Milla states "You're the one who wants to be perfect. You want me to be perfect" (72) (“Dis jý wat perfek wil wees. Jy wil hê ek moet perfek wees" [87]). 
Milla's projection of perfection is seen in her treatment and taming of Agaat, where she punishes the young Agaat for her intentional ruin of Jakkie's christening tea. Agaat acts out in order to physically manifest her displeasure at being excluded from the christening ceremony. This incident is an example of the battle between Agaat and Milla for the role of Jakkie's mother. Agaat is othered from that role, and punished for her rebellion. This punishment takes the form "rieme sit \& brei" (232), where Agaat has to work and bray thongs of leather into strips that Milla deems acceptable. This is a physical othering of Agaat; because of the deformity of her right hand, this physical task is difficult and somewhat shameful. The punishment mirrors Milla's intention:

Tanned \& brayed you must be [...] I take a raw thong \& I cut it \& show her look the core is black. Just like that it will be with you. I'll wind you up until all your black sins drip out of you \& wind you down \& wind you up again in the other direction till you're a decent servant-girl who doesn't leave one in the lurch when you need her most. She gives me that wooden eye I could slap her. $(190-1)^{12}$

Milla's process of othering and punishing Agaat others her from herself, though, as she recognises that she doesn't know herself any more, and acknowledges that she has also othered her from all of the other workers on the farm who have borne witness to this process: "I'm humiliating myself. God in heaven. [...] They look at me as if they don't know me. Do I know myself?" (193)

Another incident of chastisement that occurs when Agaat is still a child also physically others Agaat, although not through her own agency. During the scene where Milla attempts to pull Agaat out from under her bed, Milla spanks Agaat, and writes in her journal, "She must learn, my goodness" (402) ("sy moet leer, allawêreld" [487]). Milla uses her body to enforce her rule, whereas in the previous incident, Milla forced Agaat into action, but not through a physical imposition of authority. Agaat cannot, despite her attempts to manipulate Milla's bodily functions, force Milla's agency in her own rebellion, and, as such mirrors this earlier form of punishment and chastisement through language and tone when she addresses Milla. (The parallel tone is again somewhat lost in the English translation.) The mirroring of the verbal and physical incidences that othered Agaat and Milla shows the co-dependent Thirding between the subject and the object in this particular relationship. ${ }^{14}$

The establishment of the subject-object relationship originates in Milla forcibly taking Agaat from her biological family. This relationship, however, is physically contested by the child, Asgat, as she was initially named, as she breaks free from Milla's grasp and runs away from her. As Milla gains her physical grip on the child, she others Agaat's bodily instincts of escape and tries to convince the child that she is safe within the physical confines that Milla has created with her own body. After she has successfully subdued the child, she verbally claims her as well: "You're mine now" [572]) ("Jy is myne nou" [694]).The child becomes Milla's object. 
Agaat, as Milla's object, becomes an extension of Milla, serving as her eyes, her ears, and her third hand on the farm. "You are my eyes and my ears, you wanted to say" (198) ("Jy is my oë en my ore, wou jy sê" [241]). The hand that Agaat becomes in terms of the extension of Milla's body is exemplified in the scene where Milla gives birth to her son: "It would be Agaat's baby" (153) ("Dit sou Agaat se baba wees" [186]). Milla others Agaat's bodily instincts by forbidding her from becoming nauseated (184) both in terms of the birth and becoming car sick. When Milla realises that she is going to be delivering the baby en route she further others Agaat's body with the statement: "There really are not enough hands here" [152]) ("Daar is regtig nie genoeg hande hier nie" [185]). She needs Agaat's hands, but she needs more than Agaat's hands, and that others the deformed hand that Agaat would use to bring the baby out of Milla. This act would shift the power dynamic from Milla's control, even though she has been giving the verbal commands throughout the process, to Agaat, who would be inhabiting the space of Milla's body to help with the birth: "The other hand was inside you, you felt, the strong one, it reamed you as one reamed a gutter" (155) ("Die ander hand was in jou, het jy gevoel, die sterke, dit het jou geruim soos mens'n geut ruim" [188]). Despite Milla's best attempts, she cannot give birth, and she surrenders her body to Agaat's control, as Agaat takes the scissors and performs an episiotomy, and frees the child: "You strained upright, heard the scissors clatter to the ground, saw the strings dangling, slime and threads and blood out of you" (156).

As Milla uses glances, words, and body language to control Agaat's actions throughout the birthing scene, Milla instructs Agaat to move in her space, as she herself cannot, because it is "only through action and movement that a body can inhabit the space" (Farnell 343). This also recalls the words of Viljoen (50) when she writes that "'I experience the other's body as a mysterious continuation of my own, and $[\ldots]$ we are 'tied together' in a sort of anonymous existence".

\section{Conclusion}

Throughout the novel there are many other scenes that could further illustrate this dynamic between the characters, but due to spatial constraints, it is not possible to include these in this study. The aforementioned scenes, namely the bathing, the taming of Agaat, and the birthing illustrate the physical inhabitation of space through agency which oscillates between Milla and Agaat. As Milla's body is othered by her illness, Agaat inhabits the Firstspace of the room in which Milla lives for and through Milla, as Agaat's movement of Milla's body is the only agency that Milla has. The Secondspace inhabitation takes place through the emotional connection that Milla has with Agaat, especially in terms of the birth of the baby, as Milla concedes that through Agaat's agency, the baby would be Agaat's child. Milla eventually harbours resentment towards Agaat for this, but as she surrendered the birthing process, the nursing process and 
much of the raising of the child to Agaat, she has surrendered her power as a mother. In this way, Milla has essentially othered herself from that which came from her body, as she would surrender her body to the mercy and ministrations of Agaat throughout the course of her illness. Being at the mercy of Agaat's physical inhabitation of her space is mirrored by Milla's physical domination of the child Agaat, as is exemplified by Agaat's repetition of behaviours, gestures, sounds, and songs, which she employs to other Milla, and to prove her dominance within Milla's space. The Thirding that occurs is thus a spatial retaliation for the taming that Milla enforced upon the child.

When Agaat is a child, her bodily power and consequent spatial inhabitation are usurped and controlled by Milla. In the final scene, Milla's body is powerless and her spatial inhabitation is controlled by Agaat.

Ultimately, the relationship between Milla and Agaat is a cyclical power play that does not come to any true conclusion of dominance or submission because of the inhabitation that they enact through each other. As much as one is dominant over the other, she needs the other and through that need surrenders power to the other, and this cycle is then repeated. Milla's death removes the physical imposition of the othering that Agaat had experienced throughout her life on Grootmoedersdrift. Without Milla's physical inhabitation of the space that she shared with Agaat, Agaat is ultimately othered by the freedom of the potentiality of her own inhabitation in what is to become her own space.

To know the other, is to control the other. Both Milla and Agaat have such intimate knowledge of each other's bodies that there could be no true subjugation between them, because they experience one another through one another. As Burger (192) states: "The body and all the familiarity with the most intimate bodily functions between people brings in another way an intimacy, one besides that of the level of language, a possibility to be able to know" (our translation). ${ }^{15}$

Milla's death changes the nature of the Firstspace and Secondspace of Grootmoedersdrift and frees the space of the farm from her legacy by leaving the farm to Agaat. This ultimately changes the nature of the Thirdspace on the farm, as Milla relinquishes the power over the land to Agaat, just as she had relinquished power over her child, just as she had relinquished the power over herself. Agaat's final act of embracing her status as the other is the final and continual inhabitation of the land of Grootmoedersdrift.

\section{Notes}

1. "Intimacy" encompasses the level of self-disclosure between two parties. This exposure takes place in terms of the body in space, as Agaat manipulates Milla's body in the same way that Milla manipulated the body of the child Agaat. The exposure of the body leads to vulnerability, which creates the bodily spatial dynamic between the women. The physical intimacy of the relationship is bolstered by the fact that there are incidents of "confiding, expression of affection, disagreement, feelings of closeness" (Waring 11) as expressed verbally by Agaat to the ailing Milla, and by Milla in her notebooks. 
2. The term "taming" is used to demonstrate Milla's manipulation of Agaat's inhabitation of a body in space, by modifying her behaviour in order to establish the rules of the Thirdspace in which Milla is in control. In this instance, to tame means to train to conform to the Thirdspace structure of the person in power over the space. Any behaviour and spatial inhabitation other to that structure may be seen as "wild". While it falls outside the scope of this article, Fourie $(26-27,60-65)$ offers a postcolonial analysis of Milla's attempted "taming" of Agaat.

3. In Agaat there is also an exploration of othering in terms of gender. For Fourie (38-57) this mainly revolves around the novel's subversion of the male and female roles depicted in the normative plaasroman. Pretorius (42) argues that while Jak is clearly connected to "white heterosexual masculinity" and "the decline of male Afrikaner authority in the face of changing political ideologies $[. .$.$] his representation in the novel is complicated by the transient moments in which$ he does not conform to the script of hegemonic masculine domination". Finally, "the tension that governs his attempts to achieve hegemonic masculinity within an emasculated space leads to the crisis of masculinity which results in his death" (Pretorius 42). Since the analysis conducted in this article relates to the relationship between Milla and Agaat, othering in terms of gender will not be explored here.

4. The original in the Afrikaans version reads as follows: "In haar plaasroman Agaat is Van Niekerk se uitbeelding van die bruin huiswerker, Agaat Lourier, deurspek van die besef wat so kenmerkend is van die belemmerde wit postkoloniale skrywer, naamlik dat enige poging om die ander te representeer ingebed is in 'n eeue-oue koloniale diskoers oor die ander wat die geloofwaardigheid van wit skrywers van meet af aan problematiseer en ondermyn. Anders as in die koloniale periode word die postkoloniale skrywer bewus van die gelaat van die ander, nie as 'n hindernis of as 'n bedreiging waarvan die skrywende ' $e k^{\prime}$ die omvang probeer inskat nie, maar as iets waaraan die 'ek' gemeet word". (Prinsloo \& Visagie 43-4)

5. "Hoe moes dit voel om Agaat te wees? Hoe kon jy dit ooit te wete kom? Sou julle kon uitmaak wat sy sê as sy dit kon verduidelik? Sy sou dit in 'n ander taal as die een wat julle haar geleer het, moes uitlê". (574)

6. “Deur taal kan die spieëlvlak 'n ontmoetingsplek wees met die ander. Daar is die hoop by Milla dat dit moontlik sou wees. En sy en Agaat vorder in daardie rigting. Die band tussen hulle vordersy sterf immers ook met Agaat se hand in haar hand. En hiermee word ook veel meer gesêioor die moontlikheid om die ander te ken-die liggaam en al die vertroudheid met die intiemste liggaamsfunksies tussen mense bring ook op 'n ander manier as bloot die taalvlak ' $n$ intimiteit, ' $n$ moontlikheid om te kan ken" (Burger 192).

7. "Sy krink my op, sy skud my kussings, sy hys my nek uit my lyf, sy stut my kop, sy trek my reg". (82)

8. "[...] jy wil nie dalk die nommer twee pan ook hê nie, siende dat jy nou aan die gang is? [...] Mens wil nie mis en pis oor alles as jy dit kan help nie" (85).

9. “[...] anders sal ons jou maar weer 'n Pink Lady moet injaag [...] 'n Pink Lady vir die lady van Gdrift, dis vyf dae nou dat haar derms vassit. Miskien is dit wat haar so onrustig maak. Wat ingaan moet mos darem uitkom, allawêreld!" (85).

10. "Wat kan ek daarop antwoord? Watter akrobatiek van ooglede om aan te gee: Jou sarkasme is gemors op my. As ek kon doodgaan om jou te verlos, sou ek dit doen, vandag nog. Gaan soek iemand anders om perfek vir jou te pie op jou bevel. Dis jý wat perfek wil wees. Jy wil hê ek moet perfek wees. Niks mag ontbreek nie. As jy kan klaarkom sonder, moet ek kan klaarkom sonder, dis wat jy dink. 'n Volmaakte verpleegster. 'n Volmaakte pasiënt. Soos ek jou geleer het" (87).

11. "En as 'n mens se naam goed is, [sê die dominee], is dit' $n$ selfvervullende profesie. Soos ' $n$ heilige brandmerk sal dit wees, soos ' $n$ ingeboude lewenslot, die naam op die voorkop, om goed te doen, om goed te wil wees, die goedheid self" (504).

12. "gelooi \& gebrei moet jy word [...] ek vat'n róúriem \& ek sny hom \& ek was hom: Kyk die koor is swart. Net so sal dit jou vergaan. Ek sal vir jou opwen tot al jou swart sonde uit jou uitdrup \& vir jou afdraai \& weer anderkant toe opwen tot jy ' $n$ ordentlike meid is wat ' $n$ mens nie in die steek laat as jy hr die nodigste het nie. Sy gee my daardie houtoog ek kan haar klap" (232).

13. "Ek verneder my. God in die hemel. [...] Hulle kyk vir my of hulle my nie ken nie. Ken ek myself?" (235).

14. This scene also clearly illustrates Bhabha's notion of mimicry. See Fourie $(27-8,71-8)$.

15. "[D]ie liggaam en al die vertroudheid met die intiemste liggaamsfunksies tussen mense bring ook op 'n ander manier as bloot die taalvlak 'n intimiteit, 'n moontlikheid om te kan ken" (Burger 192). 


\section{Works Cited}

Ashcroft, Bill, Graham Griffiths \& Helen Tiffin. Post-Colonial Studies: The Key Concepts. London: Routledge, 2007.

Benoist, Jean. and Cathebras, Pascal. "The Body: From an Immateriality to Another". Social Sciences and Medicine 36 (1993): 857-65.

Bhabha, Homi. "Of Mimicry and Man: The Ambivalence of Colonial Discourse". October, 28 (1984): $125-33$.

Burger, Willie. "Deur ' $\mathrm{n}$ spieël in ' $\mathrm{n}$ raaisel: Kennis van die self en ander in Agaat deur Marlene van Niekerk". Tydskrif vir Taalonderrig 40 (2006): 178-93.

Buxbaum, Lara. "'Embodying Space': the Search for a Nurturing Environment in Marlene

van Niekerk's Triomf, Agaat and Memorandum". English in Africa 38 (2011): 29-44.

. "Remembering the Self: Fragmented Bodies, Fragmented Narratives in Marlene van

Niekerk's Triomf and Agaat". Journal of Literary Studies 29 (2013): 82-100.

Casey, Edward. Getting Back into Place. Bloomington. Indiana UP, 1993.

Comaroff, Jean. Body of Power, Spirit of Resistance: The Culture and History of a South African People. Chicago: U of Chicago P, 1985.

Farnell, Brenda. "Moving Bodies, Acting Selves". Annual Review of Anthropology 28 (1999): 341-73.

Featherstone, Mike \& Brian Turner. "Body \& Society: An Introduction". Body in Society 1 (1995): 1-13.

Flanagan, James. "Ancient Perceptions of Space/Perceptions of Ancient Space". Semia 85 (1995): 15-43.

Fourie, Reinhardt. "A Postcolonial and Ecocritical Reading of Marlene Van Niekerk's Modern plaasroman Agaat." MA thesis, Ghent U, 2011.

Greene, David. "Consciousness, Spatiality, and Pictorial Space". The Journal of Aesthetics and Art Criticism 14 (1983): 375-85.

Grosz, Elizabeth. Volatile Bodies: Toward a Corporeal Feminism. Bloomington: Indiana UP, 2001.

Jansen, Ena. "Ek het maar saam met die miesies gebly.' Die representasie van vrouebediendes in die Suid-Afrikaanse letterkunde: 'n steekproef." Stilet 17 (2005): 102-33.

Jensen, Sune. "Othering, Identity Formation and Agency". Qualitative Studies 2 (2011): 63-78.

Lefebvre, Henri. The Production of Space. Cambridge, MA: Blackwell, 1991.

Levinas, Emmanuel. Het menselijk gelaat. Trans. O. de Nobel. Bilthoven: Ambo, 1969.

Low, Setha. "Embodied Space(s): Anthropological Theories of Body, Space, and Culture". Space and Culture 6 (2003): 9-18.

Matthews, Victor. More Than Meets the Ear. Michigan, MI: Eerdmans, 2008.

McGuire, Merideth. "Religion and the Body: Rematerialising the Human Body in the Social Sciences of Religion". Journal for the Scientific Study of Religion 29 (1990): 283-96.

Pilch, John. "Biblical Leprosy and Body Symbolism". Biblical Theology Bulletin: A Journal of Bible and Theology, 11 (1981): 108-13.

Prinsloo, Loraine \& Andries Visagie. “Die representasie van die bruin werker as die ander in Marlene van Niekerk se postkoloniale plaasroman Agaat (2004)". Stilet 19 (2007): 43-62.

Schildkrout, Enid. "Inscribing the Body". Annual Review of Anthropology 33 (2004): 319-44.

Soja, Edward. Thirdspace: Journeys to Los Angeles and Other Real-and-Imagined Places. Malden, MA: Blackwell, 1996.

Tuan, Yi-Fu. Space and Place: The Perspective of Experience. Minnesota: U of Minnesota P, 1977.

Van Niekerk, Marlene. Triomf. Cape Town: Queillerie, 1994. . Agaat. Cape Town: Tafelberg, 2004.

The Way of the Women. Trans. Michiel Heyns. London: Abacus, 2006.

Viljoen, Marga. The Body as Inhabitant of Built Space: the Contribution of Maurice Merleau-Ponty and Don Ihde. MA thesis, U of Pretoria, 2009.

Waring, E.M. "Editorial: Measurement of Intimacy: Conceptual and Methodological Issues of Studying Close Relationships". Psychological Medicine 15 (1985): 9-14.

Waskul, Dennis and Philip Vannini, eds. Body/Embodiment: Symbolic Interaction and the Sociology of the Body. Burlington: Ashgate, 2006.

West-Pavlov, Russel. Space in Theory: Kristeva, Foucault, Deleuze. New York: Rodopi, 2009. 